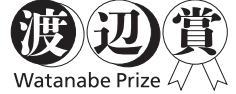

\section{一第 94 回渡辺賞受賞一 \\ 岩盤切削機の石灰岩採掘現場への 導入とその効果 *}

\title{
Introduction of Rock Cutting Machine "2500SM" into Limestone Mining Site and Its Effect
}

\author{
by Yasuhiko OKAMOTO ${ }^{\mathrm{a}}$, Masaki KAWAHATA ${ }^{\mathrm{b}}$, \\ Tomoyuki SHOUDAI ${ }^{\mathrm{c}}$ and Kouhei TSUJIMOTO ${ }^{\mathrm{c}}$
}
a. OKUMURA Engineering Corporation. 1-11-18, Misaki, Minato-ku, Osaka-shi, Osaka, 552- 0016, Japan (Corresponding author, E-mail: y.okamoto@okumuradbk.co.jp)
b. OKUMURA Engineering Corporation. 6-1-3, Benten, Minato-ku, Osaka-shi, Osaka, 552-0007, Japan
c. UBE Industries, LTD. 4768, Isa, Isa-cho, Mine-shi, Yamaguchi, 759-2222, Japan

\begin{abstract}
Ube Industries' Isa Cement Factory introduced a rock cutting machine "2500SM" capable of continuous excavation by rotating a drum equipped with a cemented carbide bit from the viewpoint of effective recovery limestoneresources. Because it can excavate with low vibration and low noise, it can reduce the distance from the surrounding private houses that have been secured in consideration of the effect of blasting, and in order not to loosen the excavated surface, the bench angle of the excavated surface is steeply inclined and berm is minimized. It was because it was judged that the minable amount could be expanded by minimizing the berm.

In the early stages of the introduction, cutting bits were broken unexpectedly, and the frequency of replacement increased, resulting in a decrease in mining efficiency. In addition, the excavation slope using a rock cutting machine "2500SM" has a smoother surface and no large cracks. In addition, in the evaluation using methods of elastic wave exploration, ground penetrating radar and infrared camera, the slope of excavation is compared with that by blasting. It was confirmed that the soundness was high.

The effects of cutting bit improvements was evaluated, the expected excavation area, the soundness and safety of the rock slope, and the expansion of the minable amount that were expected when the rock cutting machine "2500SM" was introduced. In this paper,we repot the evaluation results.
\end{abstract}

KEY WORDS: Rock Cutting Machine, 2500SM, Final Rock Slope, Minable Amount, Low Noise and Vibration, Proximity Construction

\section{1.は じめに}

石灰石鉱山での採掘作業は発破工法によるのが一般的である。 宇部伊佐鉱山では, 周辺に多数の民家が存在するという制約から, 民家に近い上部切羽の採掘が遅れ，下部の主力採掘切羽が狭小に なるという問題が顕在化しつつある。このことは長期的には鉱山 全体の可採鉱量の減少に繋がるため, 有効な対策を模索していた。

また，鉱山における残壁については，長期に渡る安定性が求め られる。通常行われる階段掘削では，発破孔を段の高さよりも長 く削孔し，法尻の下部まで破砕することで小段を平坦に仕上げや すくしている。この方法では, 法面・法肩部に浮き石を生じさせ

*2020 年 1 月 27 日受付 2020 年 6 月 4 日受理 2020 年 9 月「資源・素材 2020 (仙台)」(オンライン開催) にて講演予定

1. 正会員 奥村組土木興業株式会社 環境開発本部 技術部 技術マネジャー

2. 奥村組土木興業株式会社 環境開発本部 特殊工事課長

3. 宇部興産株式会社建設資材カンパニー生産・技術本部 鉱業部長

4. 宇部興産株式会社建設資材カンパニー 生産・技術本部 鉱業部 資源グルー プ

[ 著者連絡先 ] E-mail: y.okamoto@okumuradbk.co.jp

キーワード : 岩盤切削機, $2500 \mathrm{SM}$ ，残壁の安全性，採鉱量の増加，低騒音・ 低振動，近接施工
やすく, 落石の危険性がある。とくに最終残壁では, 法面保安の ためにモルタル吹付けや落石防護ネットの設置, 法面変位の監視 などが必要となってくるが, 費用と手間の負担が大きく, 全ての 残壁に対して実施することは困難である。

こうした課題の解決策として, 当鉱山では, 石灰石鉱山の最終 残壁の造成としては国内初となる, 岩盤切削機を採用することと した。このため法面近傍での掘削を実施し, 岩盤切削機の掘削能 力や環境影響の評価, 岩盤特性に合わせた切削ビットの改良, 発 破と機械掘削による残壁に対する健全性の比較と評価を行った。

\section{2. 岩盤切削工法}

\section{$2 \cdot 1$ 工法の選定}

民家に近接している箇所での騒音，振動，粉塵などの環境負荷 が小さいこと，掘削能力が大きくトン当たりのコストができるだ け低く抑えられること, 健全な残壁が形成できることなどを要件 として検討した結果，岩盤切削工法を選定した。

これまでは割岩機を導入し,特に端縁部の掘削を行っていたが, 露頭状態の岩石を破砕するのには適しているものの, 本来の目的 


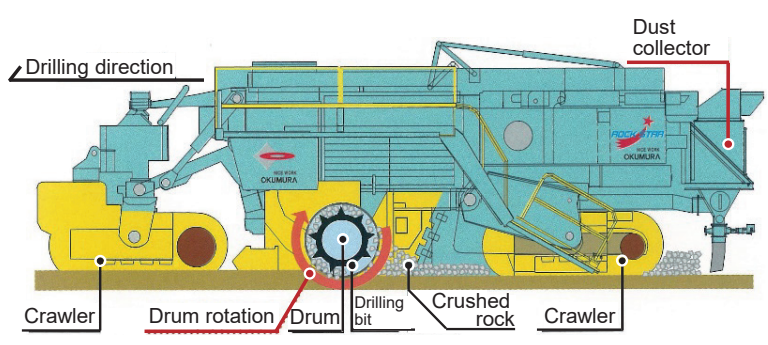

Fig.1 Structure diagram of rock cutting machine "2500SM"
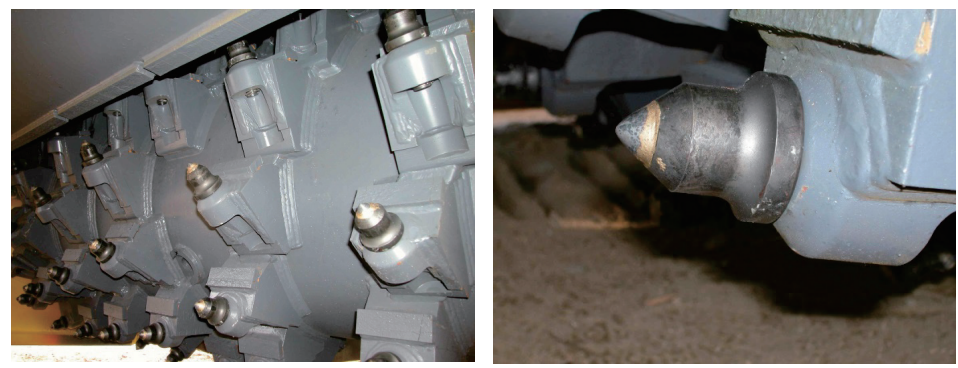

Fig.3 Drilling rotary drum and bit enlarged view.

Table 1 Specifications of rock cutting machine "2500SM".

\begin{tabular}{c|c|c}
\hline \multirow{2}{*}{ Classification } & \multicolumn{2}{|c}{ Specification } \\
\hline \multirow{2}{*}{ Size } & Length/Width/Height & $12.9 \mathrm{~m} / 3.71 \mathrm{~m} / 4.09 \mathrm{~m}$ \\
\hline \multirow{4}{*}{ Gross Weight } & When working & $133 \mathrm{t}$ \\
\cline { 2 - 3 } & Cutting width / maximum cutting depth & $2.50 \mathrm{~m} / 0.35 \mathrm{~m}$ \\
\cline { 2 - 3 } & Diameter / Number of bits & $1.4 \mathrm{~m} / 114$ pieces \\
\hline \multirow{5}{*}{ Engine } & Drum rotation speed & $47 \mathrm{rpm}$ \\
\cline { 2 - 3 } & Name & Cummins QST30-1200 ps \\
\cline { 2 - 3 } & Displacement & $30,500 \mathrm{cc}$ \\
\cline { 2 - 3 } & Rated output & $1,217 \mathrm{ps} / 2,100 \mathrm{rpm}$ \\
\cline { 2 - 3 } & Fuel tank capacity & 2,750 liter \\
\cline { 2 - 3 } Driving performance & Work speed & $0 \sim 25 \mathrm{~m} / \mathrm{min}$ \\
\cline { 2 - 3 } & Running speed & $0 \sim 3.9 \mathrm{~km} / \mathrm{h}$ \\
\cline { 2 - 3 } & Uphill ability & $20 \mathrm{degrees}(36 \%)$ \\
\hline
\end{tabular}

である民家に近い箇所を採掘するには掘削能力が低く，効果を発 揮できなかった。ツインヘッダについても検討したが，騒音や粉 塵の問題から適用は困難だと判断した。

\section{$2 \cdot 2$ 岩盤切削機}

岩盤切削機 ${ }^{1)}$ (2500SM : Surface Miner: ドラム幅 $2500 \mathrm{~mm}$ ) は, ビットを螺旋状に取り付けた掘削用回転ドラムを胴体中央部に配 置し，切削機の自重を反力にして，切削ドラムをすくい上げるよ うに回転させて (アップカット) 連続的に岩盤を掘削するもので ある (Fig. 1)。Fig. 2 に作業状況, Fig. 3 に掘削用回転ドラムお よび切削ビットを示す。仕様は Table 1 に示す

岩盤切削機の主な特長は以下の 4 つである。

(1) 掘削能力が大きい軟岩から硬岩領域までの掘削が可能で ある。岩盤等級ごとの掘削能力は, 中硬岩 ( 地山弾性波速度 : 2.0 $\sim 2.9 \mathrm{~km} / \mathrm{sec}$ ) の場合 $200 \sim 250 \mathrm{~m}^{3} /$ 日、硬岩 (地山弾性波速度 : 2.9 $\sim 4.2 \mathrm{~km} / \mathrm{sec}$ ) の場合 $50 \sim 100 \mathrm{~m}^{3} /$ 日である。当該䇢所の石灰石は, 軟岩〜中硬岩に該当する。

（2）環境への影響が小さい＼cjkstart掘削時の騒音，振動が小さいため
民家に接近して作業ができる。また，ドラム部における散水 ( 毎 分 50 l), 搭載している集塵機などによる粉塵の飛散防止が可能 である。

（3）岩砕の最大粒径が $100 \sim 150 \mathrm{~mm}$ 以下になる＼cjkstart岩砕の最大 粒径は $100 \sim 150 \mathrm{~mm}$ 以下となるため, そのまま路床材として使 用できる。また，ビットの本数や配置を変えることで最大粒径を コントロールすることも可能である。

（4）掘削面の仕上がり精度が高く，平坦性が良い オペレータ がレーザーレベル計のデータを確認しながら掘削深さや縦断勾配 をコントロールするため, 仕上がり面の高さ精度は設計值の土 $3 \mathrm{~cm}$ 以内となる。掘削面が平坦となり, 現場の安全性が向上する。

\section{3. 導 入 実 績}

\section{$3 \cdot 1$ 掘削作業および掘削実績}

2012 年度に岩盤切削機を導入した丸山鉱区 (Fig. 4) は, 民家に 近接している鉱区であり, 最も近い䇢所では $150 \mathrm{~m}$ 程度 ${ }^{2)}$ であっ た。そのため, 発破規模を縮小寸ることになり, 採掘の遅れの回 


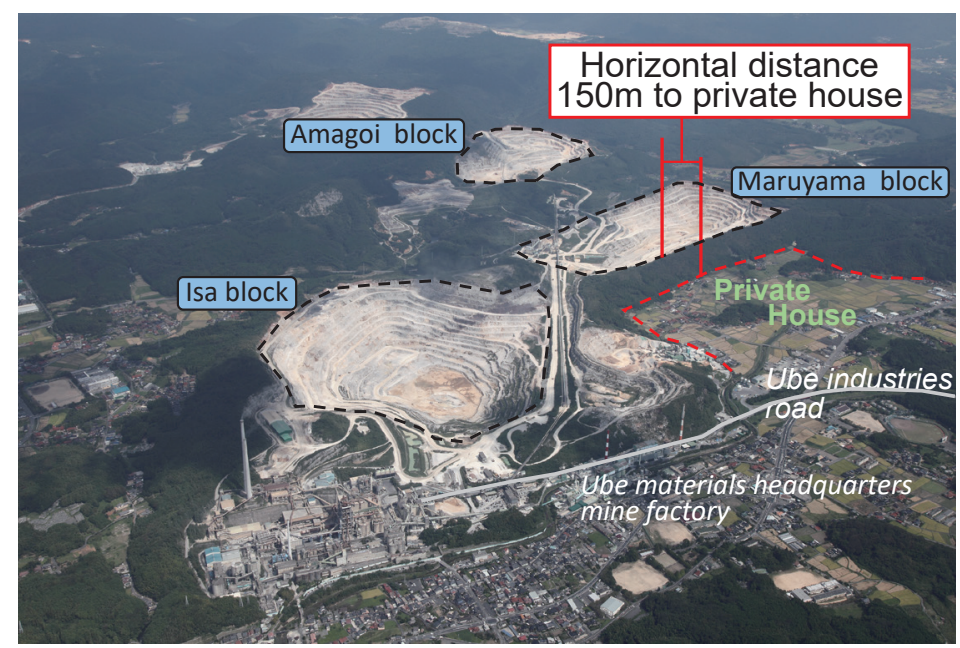

Fig.4 Status of Ube Isa Mine.

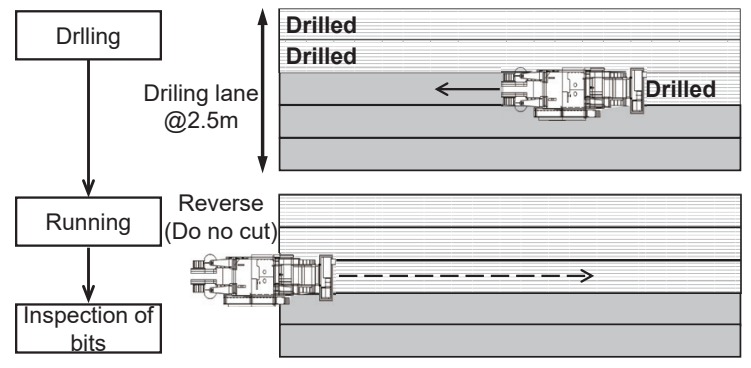

Fig.5 Work cycle.

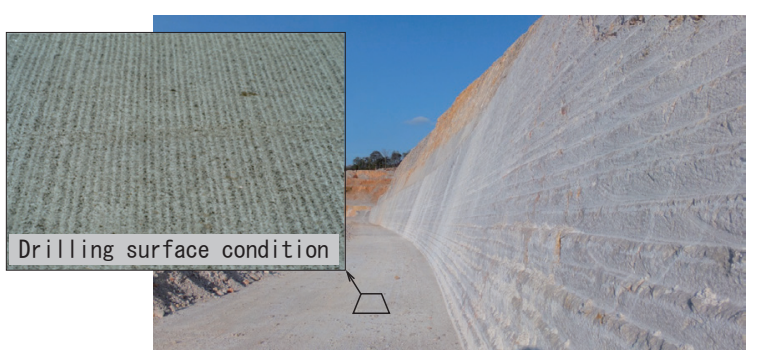

Fig.6 Slope after drilling (average gradient 60 degrees).

Table 2 Drilling results.

\begin{tabular}{c|c|c|c|c|c|c}
\hline Year & Working days & $\begin{array}{c}\text { Drilling amount } \\
\left(\mathrm{m}^{3} / \mathrm{t}\right)\end{array}$ & Number of bits & $\begin{array}{c}\text { Bit usage } \\
(\text { Number / t })\end{array}$ & $\begin{array}{c}\text { Number of } \\
\text { breakage }\end{array}$ & $\begin{array}{c}\text { Breakage ratio } \\
(\%)\end{array}$ \\
\hline 2012 & 120 & $15,162 /$ about 41,000 & 1,954 & 0.05 & 1,163 & 59.5 \\
\hline 2013 & 112 & $14,461 /$ about 39,000 & 1,826 & 0.05 & 1,394 & 76.3 \\
\hline 2014 & 110 & $16,585 /$ about 45,000 & 1,658 & 0.04 & 2 & 0.12 \\
\hline 2015 & 167 & $19,531 /$ about 53,000 & 3,309 & 0.06 & 218 & 6.59 \\
\hline 2016 & 211 & $19,794 /$ about 53,000 & 1,178 & 0.02 & 5.50 \\
\hline 2017 & 210 & $22,828 /$ about 62,000 & 1,364 & 0.02 & 54 & 3.96 \\
\hline 2018 & 185 & $21,152 /$ about 57,000 & 1,217 & 0.02 & 39 & 3.20 \\
\hline
\end{tabular}

Table 3 Example of cycle time.

\begin{tabular}{c|c|c|c|c|c|c|c|c|c}
\hline $\begin{array}{c}\text { Work } \\
\text { type }\end{array}$ & Idling & Drilling & Running & $\begin{array}{c}\text { Inspection } \\
\text { of bit }\end{array}$ & Break & Other & Total & \begin{tabular}{c} 
Drilling amount \\
\cline { 4 - 8 }
\end{tabular} \\
\hline $\begin{array}{c}\text { Time } \\
\text { (h) }\end{array}$ & 0.139 & 5.5 & 0.664 & 0.856 & 1.15 & 0.64 & 8.949 & $\begin{array}{c}570 \\
\mathrm{t} / \text { day drilling }\end{array}$ & $\begin{array}{c}\text { Net drilling } \\
\text { capacity }\end{array}$ \\
\hline$\%$ & 1.55 & 61.46 & 7.42 & 9.57 & 12.85 & 7.15 & 100 & \\
\hline
\end{tabular}

復が懸案であった。

Fig. 2 に示す岩盤切削機で掘削した岩石の集積，積込，運搬に はブルドーザ，バックホウ，ダンプトラックを使用する。Fig. 5 に作業サイクルを示す。掘削レーンの幅は $2.5 \mathrm{~m}$ である。 1 レー ン (長さは平均 $100 \mathrm{~m}$ 程度) の採掘が終了したら後進走行し, 隣 のレーンに移って掘削を繰り返す。1 レーンの採掘サイクルの中 でビットの点検・交換作業を行う。

\section{$3 \cdot 2$ 掘削後の法面や基面の状況}

掘削後の法面の状況を Fig. 6 に示す。階段状のきれいな掘削法 面となっている。落石の心配がないので緩傾斜にする必要がなく, 小段も最小幅で良い。掘削後の基面も平滑で，砕石を敷かなくて も運搬道路として使用できる。

\section{$3 \cdot 3$ 掘削能力}

岩盤切削機による掘削を開始した 2012 年度からの掘削量を Table 2 に示す。掘削のサイクルタイム計測結果をTable 3 に示す。 


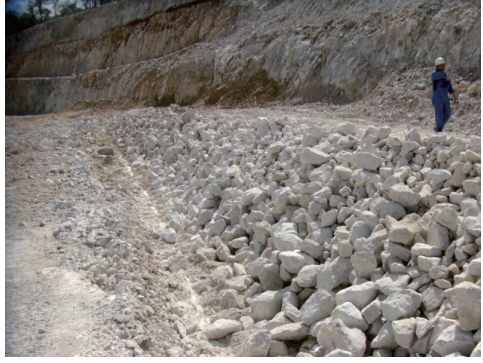

Drilled rock near the surface layer

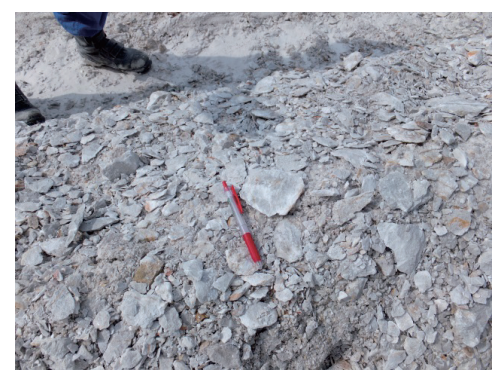

Drilled rock about $5 \mathrm{~m}$ deep from the surface

Fig.7 Fig. Drilled rock conditions (same scale on left and right).

移動時間, ビット点検時間などを除いて掘削能力を算出すると, 概ね $100 \sim 150 \mathrm{t} /$ 時間であった。移動時間，ビット交換時間など を考慮すると，掘削作業時間は約 5 時間/ 日であり, 1 日あたり の掘削量は $500 \sim 750 \mathrm{t} /$ 日である。割岩機での掘削量が約 $100 \mathrm{t} /$ 日であるから，それに比べると掘削能力は非常に高い。掘削能力 に幅があるのは，岩盤の硬さや亀裂の影響である。表層部分は過 去の発破 ( 1 ベンチ上のサブドリル部) の影響を受けて亀裂が多 く, 強度も低下しているが, 深くなるにつれて固い石灰石の岩盤 となる。Fig. 7 に示寸掘削岩の状況を見ると, 表層付近では粒度 が比較的大きく, 球形に近いものが多いのに対し, 掘削深度が深 くなり岩盤が固くなるとチップ状になって細粒化しており，上記 のような岩盤の状態を反映した結果となっている。

\section{$3 \cdot 4$ 騒音, 振動, 粉塵などの環境影響 3 )}

掘削中の騒音・振動はともに低い值で ${ }^{3)}$, 環境への影響は非 常に小さい。特に振動值は, $30 \mathrm{~m}$ 離れると $30 \mathrm{~dB}$ 程度となるた め, 民家に接近して掘削することも可能である。騒音については、 $30 \mathrm{~m}$ 離れると $78.2 \mathrm{~dB}$ となる。参考值であるが，小割機は $83 \mathrm{~dB}$ であった。また, 粉塵に関しても, 切削機本体に搭載しているバ グフィルターによる濾過および掘削ドラムへの散水により, 粉じ んの発生を抑えている ${ }^{4)}$ 。掘削中の様子を示した Fig. 2 でも, 粉 塵の発生はみられない。

$3 \cdot 5$ 消耗品 (切削ビット)

コストに最も影響の大きい消耗品は切削ビットである。Table 2 に過去 7 年間のビット消費量 (交換本数 / 掘削土量) を示す。消 費量は岩石中の鉱物や亀裂の状況などによって変動するが，7 年 間の平均值は 0.04 本 $/ \mathrm{t}$ 程度であり, 年度毎の変動幅は小さい。 当鉱山での掘削開始当初はビットの折損が多発し，掘削岩に紛れ 込んだビットの探索や交換作業に時間を要したことが掘削能力の 低下の原因となっていたため, 対策が必要であった。

\section{4. 切削ビットの改良 ${ }^{5)}$}

岩盤切削機での掘削作業を行う過程で，石灰石の掘削作業には 何ら問題ないことが確認できた。しかしながら前項で述べたよう に,ビットの折損が頻発した。

\section{$4 \cdot 1$ 問題点}

掘削岩を 1 次クラッシャーに投入するため, 折損したビットが 混入していると製品のコンタミや破砕設備の損傷などが発生する 懸念があった。また, 破損片の探索, ビット交換作業, アイドリ ングタイムの確保などによる掘削時間の減少といった問題も発生 する。

$4 \cdot 2$ ビット折損のメカニズム

通常は Fig. 8 に示すように, 軸対象の磨耗が進行し (ビットが 回転することによるセルフシャープニングの効果) , 限界に至っ た時点でビットの交換を行う。しかしながら当鉱山での掘削作業 においては, Fig. 9 に示寸ように, 超硬チップが磨耗限界に至る

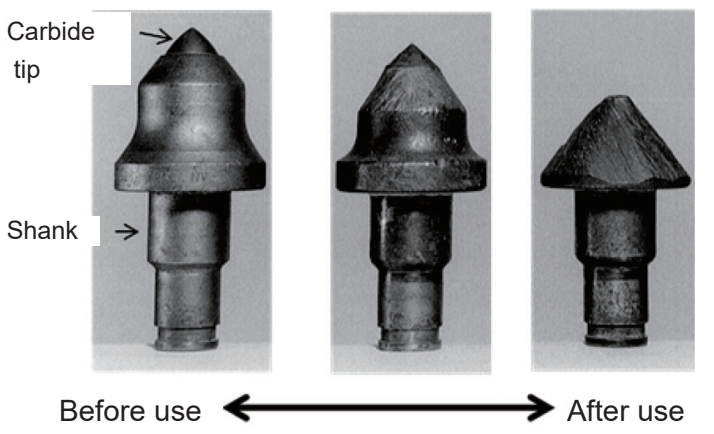

Fig.8 Bit standard wear process

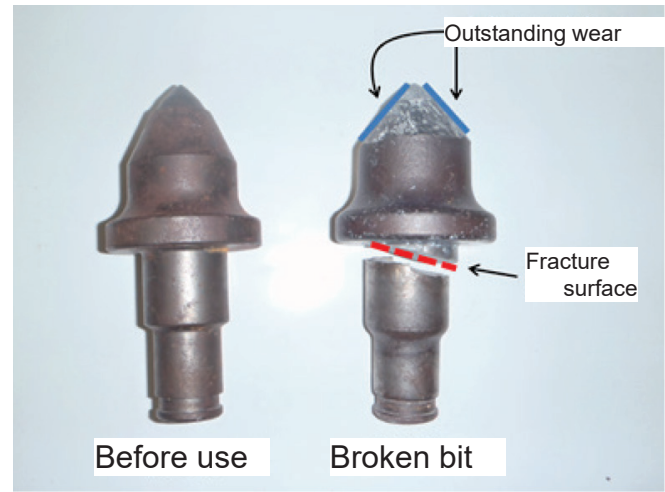

Fig.9 Bit breakage.

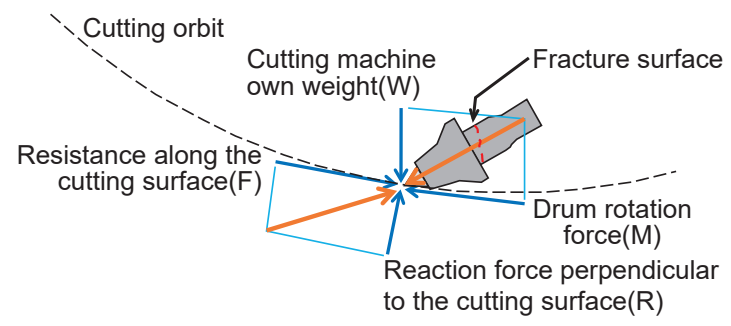

Fig.10 Bit breakage mechanism.

前にシャンクの部分が折損する事例が頻発した。

Fig. 10 に示すように, ビットには, 岩盤からの反力として, 切削面に沿った抵抗力 $\mathrm{F}$ と切削面に垂直な反力 $\mathrm{R}$ が作用する。 石灰岩は粘り強いため, $\mathrm{F}$ の值が大きくなってビット軸に対して 垂直に作用寸る荷重が増加したことが原因ではないかと考えてい る。折損したビットの大半は, 卓越した磨耗面と破断面が Fig. 9 のような位置関係となっている。

\section{$4 \cdot 3$ 各種ビットのテスト}

ビット折損のメカニズムを考慮し, シャンクの硬度および径の 
Table 4 List of used bits

\begin{tabular}{c|c|c|c|c}
\hline & Name & Bit diameter & Tip diameter & Shank hardness \\
\hline Standard bit & WSM-25 & $38 \mathrm{~mm}$ & $25 \mathrm{~mm}$ & HRC44-48 \\
\hline Hardness change & $\begin{array}{c}\text { WSM-25 } \\
\text { (Hardness change) }\end{array}$ & $38 \mathrm{~mm}$ & $25 \mathrm{~mm}$ & HRC38-42 \\
\hline Bit A & WSM1-17-77/42LR & $42 \mathrm{~mm}$ & $17 \mathrm{~mm}$ & HRC44-48 \\
\hline Bit B & WSM1-22-77/42LR & $42 \mathrm{~mm}$ & $22 \mathrm{~mm}$ & HRC44-48 \\
\hline
\end{tabular}

Table 5 Test 2 result.

\begin{tabular}{|c|c|c|c|c|c|c|c|}
\hline \multirow{2}{*}{ Used bits } & \multirow{2}{*}{$\begin{array}{l}\text { Shank diameter / } \\
\text { Tip diameter }\end{array}$} & \multirow{2}{*}{$\begin{array}{l}\text { Daily drilling } \\
\text { (day) }\end{array}$} & \multirow{2}{*}{$\begin{array}{l}\text { Total drilling } \\
\text { amount } \\
\left(\mathrm{m}^{3}\right)\end{array}$} & \multirow{2}{*}{$\begin{array}{l}\text { Drilling amount } \\
\left(\mathrm{m}^{3} / \text { day }\right)\end{array}$} & \multicolumn{2}{|c|}{ Number of wear } & \multirow{2}{*}{$\begin{array}{c}\text { Number of } \\
\text { breakage }\end{array}$} \\
\hline & & & & & All & Per1 $\mathrm{m}^{3}$ & \\
\hline $\begin{array}{l}\text { Standard bit } \\
\text { WSM-25 }\end{array}$ & $38 \mathrm{~mm} / 25 \mathrm{~mm}$ & 11 & 1,454 & 132 & 154 & 0.106 & 133 \\
\hline $\begin{array}{c}\text { Bit A } \\
\text { WSM1-17-77/42LR }\end{array}$ & $42 \mathrm{~mm} / 17 \mathrm{~mm}$ & 11 & 1.888 & 172 & 232 & 0.123 & 1 \\
\hline
\end{tabular}

Table 6 Test 3 result

\begin{tabular}{|c|c|c|c|c|c|c|c|}
\hline \multirow{2}{*}{ Used bits } & \multirow{2}{*}{$\begin{array}{l}\text { Shank diameter / } \\
\text { Tip diameter }\end{array}$} & \multirow{2}{*}{$\begin{array}{l}\text { Daily drilling } \\
\text { (day) }\end{array}$} & \multirow{2}{*}{$\begin{array}{l}\text { Total drilling } \\
\text { amount } \\
\left(\mathrm{m}^{3}\right)\end{array}$} & \multirow{2}{*}{$\begin{array}{l}\text { Drilling amount } \\
\qquad\left(\mathrm{m}^{3} / \text { day }\right)\end{array}$} & \multicolumn{2}{|c|}{ Number of wear (number) } & \multirow{2}{*}{$\begin{array}{c}\text { Number of } \\
\text { breakage } \\
\text { (number) }\end{array}$} \\
\hline & & & & & All & Per $1 \mathrm{~m}^{3}$ & \\
\hline $\begin{array}{l}\text { Bit A WSM1- } \\
\text { 17-77/42LR }\end{array}$ & $42 \mathrm{~mm} / 17 \mathrm{~mm}$ & 26 & 3,808 & 146 & 453 & 0.119 & 0 \\
\hline $\begin{array}{l}\text { Bit B WSM- } \\
22-77 / 42 L R\end{array}$ & $42 \mathrm{~mm} / 22 \mathrm{~mm}$ & 31 & 5,339 & 172 & 214 & 0.04 & 1 \\
\hline
\end{tabular}

変更の 2 つの観点から折損防止対策を検討した。その過程でビッ 卜を試作し, 掘削を行って折損や掘削の状況を確認した。なお, 岩盤の状態によって掘削条件が大きく変わるため, 期間を定め, 同一条件となるよう配慮して比較を行った。以下に, 試作したビッ トの概要と掘削テストの結果を示す。Table 4 にテストに使用し たビット仕様の一覧を示す。

（1）テスト1 (硬度の変更）掘削開始当初に使用していた標 準ビットは，想定した石灰石の圧縮強度から，シャンク硬度が HRC44-48 のものを使用していたが，硬度は高いものの割れやす いという弱点があった。そこでシャンク硬度を HRC38-42 に下げ て勒性を増すことにしたが，大きな改善は見られなかった。

（2）テスト 2 ( シャンク径の変更）シャンク硬度は変えずに シャンク径を $38 \mathrm{~mm}$ から $42 \mathrm{~mm}$ に変更したビットA (WSM1-1777/42LR： $\phi 42 \mathrm{~mm}$ ，チップ径 $17 \mathrm{~mm}$ ) を使用して掘削を行った。 ビット A はシャンク断面積が標準ビットの約 $20 \%$ 増となり, 曲 げ剛性 (断面 2 次モーメント) が約 50\% 増となっている。

同一箇所での標準ビットと比較した結果, Table 5 に示すよう にビットの折損本数が, 標準ビットの 133 本に対して, 掘削の全 体量が多いにも関わらずビット A では 1 本のみとなり，第一の 目的は達成できた。

（3）テスト3 ( チップ径の変更）＼cjkstart次にビットの損耗低減を新た な課題とした。そこで, シャンク径 $42 \mathrm{~mm}$, チップ径を $22 \mathrm{~mm}$ としたビットB (WSM-22-77/42LR； $\phi 42 \mathrm{~mm})$ で掘削を行った。 その結果を Table 6 に示す。掘削 $1 \mathrm{~m}^{3}$ あたりのビット損耗本数 について, ビット A を基準に標準ビットとビット B を比較すると, テスト 2 では, 標準ビット/ビット $\mathrm{A}=0.106 / 0.123=0.862$, テ スト 3 では, ビット B/ビット $\mathrm{A}=0.040 / 0 。 119=0.336$ となり, ビット B が標準ビットの $40 \%$ 程度 $(\fallingdotseq 0.336 / 0.862)$ になることが 分かった。したがって 2015 年 9 月以降はビットBを使用している。

Table 2 に稼動を開始した 2012 年から 7 年間のビット使用量お よび折損本数の推移を示す。ビット形状を変更した 2014 年以降
は折損比率 (折損本数/ビット本数) が大幅に低下しており, 作 業効率の向上にも大きく寄与している。

\section{5. 残壁の健全性評価 ${ }^{6)}$}

$5 \cdot 1$ 対象残壁の概要 健全性評価のために 3 つの残壁を選 定した。岩盤切削機のみで掘削した箇所を残壁 1 とし、7 年前に プレスプリッティングを行って造成した残壁の表面を, 今回の調 査のために岩盤切削機で再掘削した箇所を残壁 2 とした。残壁 3 は今年度にプレスプリッティングによって造成した箇所である。

また, Fig. $11 \sim$ Fig. 13 は測線沿いの断面図で, 写真測量によっ て構築した 3 次元モデルを基に作成した。図中の番号は弾性波探 查で用いた加速度センサーを設置した測点を示す。

$5 \cdot 2$ 計測項目岩盤切削機を使って整形した残壁は平滑で, 健全性が高いと考えられる。確証を得るため, 発破により整形し た残壁と比較し, 掘削エネルギーが残壁に与える損傷の影響を調 查した。調查方法は, 地盤評価で用いられることが多い「屈折法 による弾性波探查」,「地中レーダ」とし, さらに物質表面の温度 を把握できる「赤外線カメラ」による撮影を行った。

（1）屈折法による弾性波探査岩盤内を伝搬する $\mathrm{P}$ 波速度の違 いを利用して，はぎとり法により損傷域の深度分布を評価した。 Fig. 14 (a) のような速度型の振動センサーを用い、地面と平行に 約 $1 \mathrm{~m}$ 間隔で, 直径 $10 \mathrm{~mm}$ 程度, 深さ $5 \mathrm{~cm}$ 程度の孔を開け, 粘 土を充填した後, ピンを押し込んで振動センサー (速度型) を固 定した。測定の様子を Fig. 14 (b) に示す。

（2）地中レーダ $400 \mathrm{MHz}$ 帯域のアンテナを使用して, 損傷域 と健全部の境界の検出を試みた。境界部でレーダ波が反射すれば 画像として反射領域が表示できる。残壁に沿って測定が可能にな るように装置を作成し， 2 名で測定を行った。残壁 2 での測定の 様子を Fig. 15 (a) に示す。残壁 3 では, 表面形状が滑らかでない ため, Fig. 15 (b) に示すように, アンテナを抱えながら測定した。 （3）赤外線カメラ 赤外線カメラは対象物の表面から放射され 


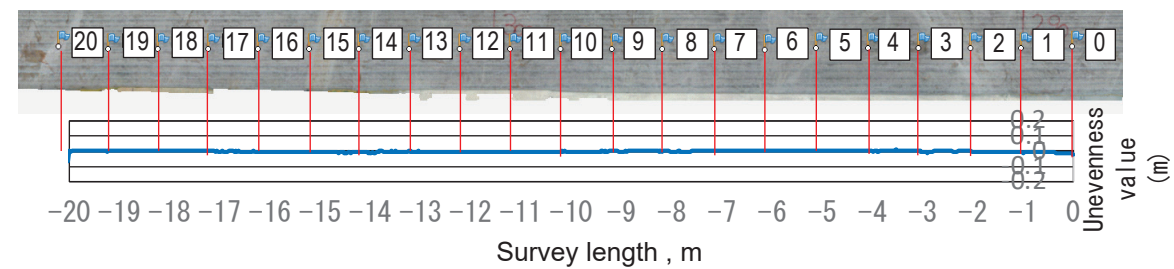

Fig.11 Rock slope 1 Final Rock slope with rock cutting machine.

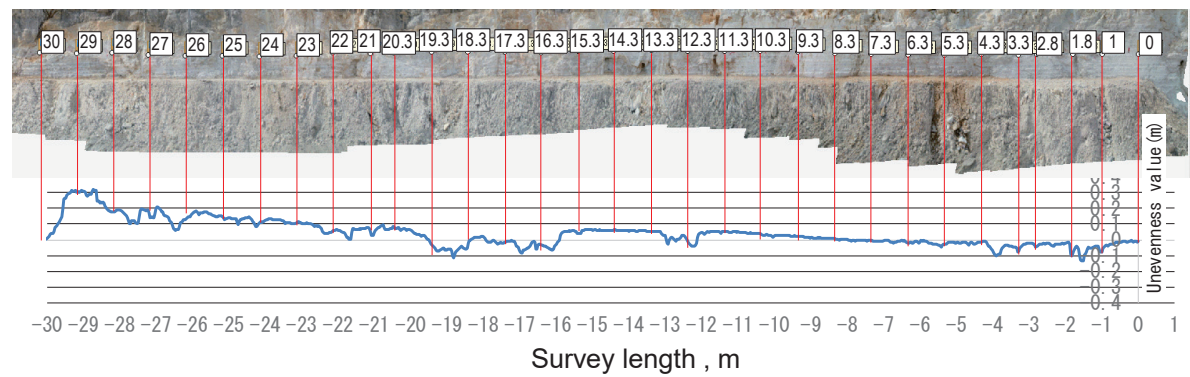

Fig.12 Rock slope 2 The final Rock slope smoothed with a rock cutting machine after press pre-splitting.

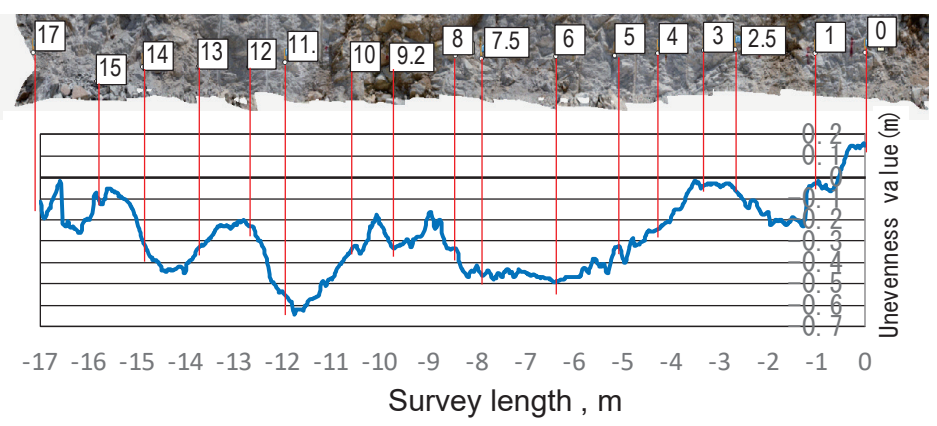

Fig.13 Rock slope 3 Final Rock slope by pre-splitting.

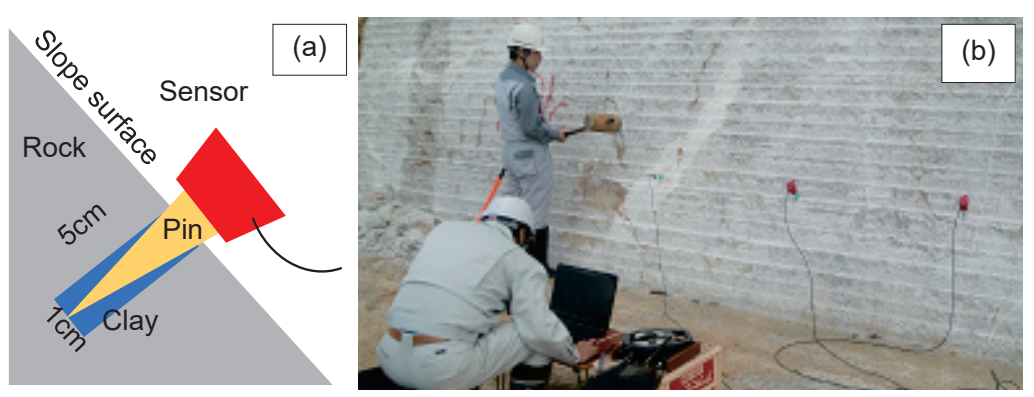

Fig.14 Implementation status of elastic wave exploration by refraction method.
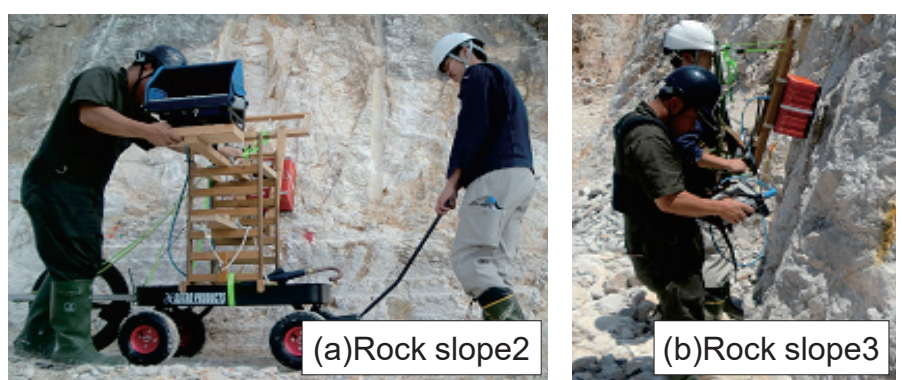

Fig.15 State of measurement

る熱エネルギー量を検出するものである。対象物の表面状態 (色, 角度）によって熱の反射率が異なるため，対象物に対して正面・ 右・左と撮影角度を変えた。撮影のタイミングは，熱の供給の多 い昼頃に撮影した。撮影担当者は 1 名である。
$5 \cdot 3$ 計測結果

$5 \cdot 3 \cdot 1$ 屈折法による弾性波探査

(1) 計測波形 残壁 1 , 残壁 2 , 残壁 3 における弾性波計測波形は, Fig. $16 \sim$ Fig. 18 のようであった。各測線で往復の計測を実施し 

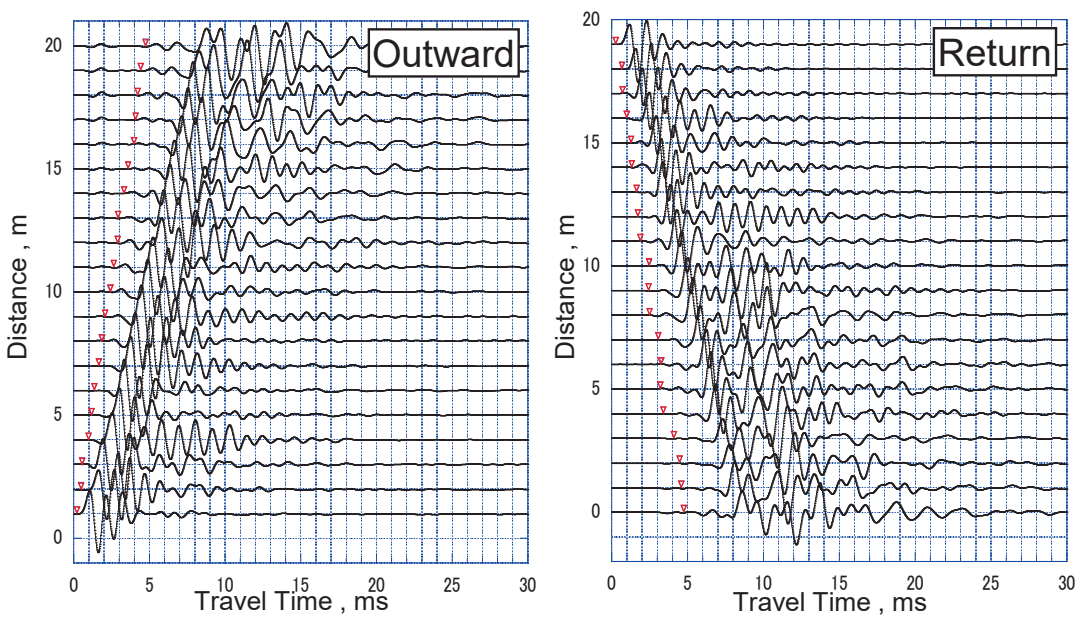

Fig.16 Measurement waveform of rock slope1.
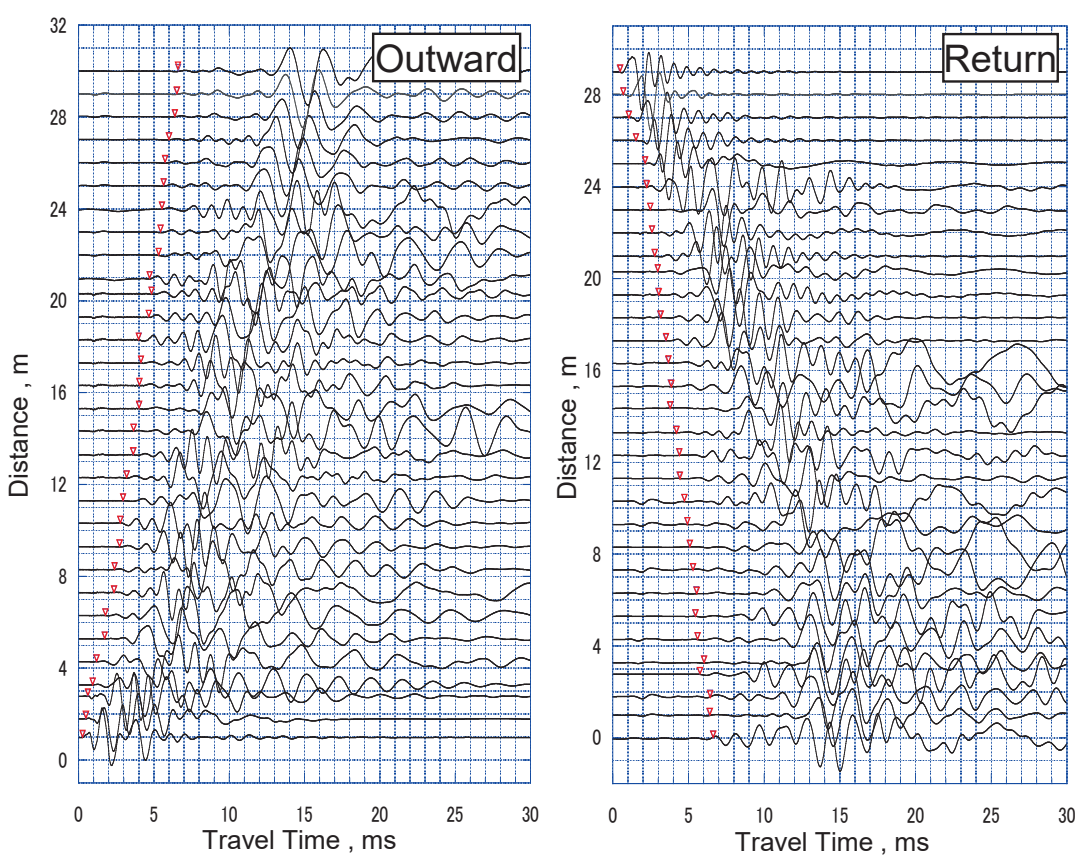

Fig.17 Measurement waveform of rock slope2.
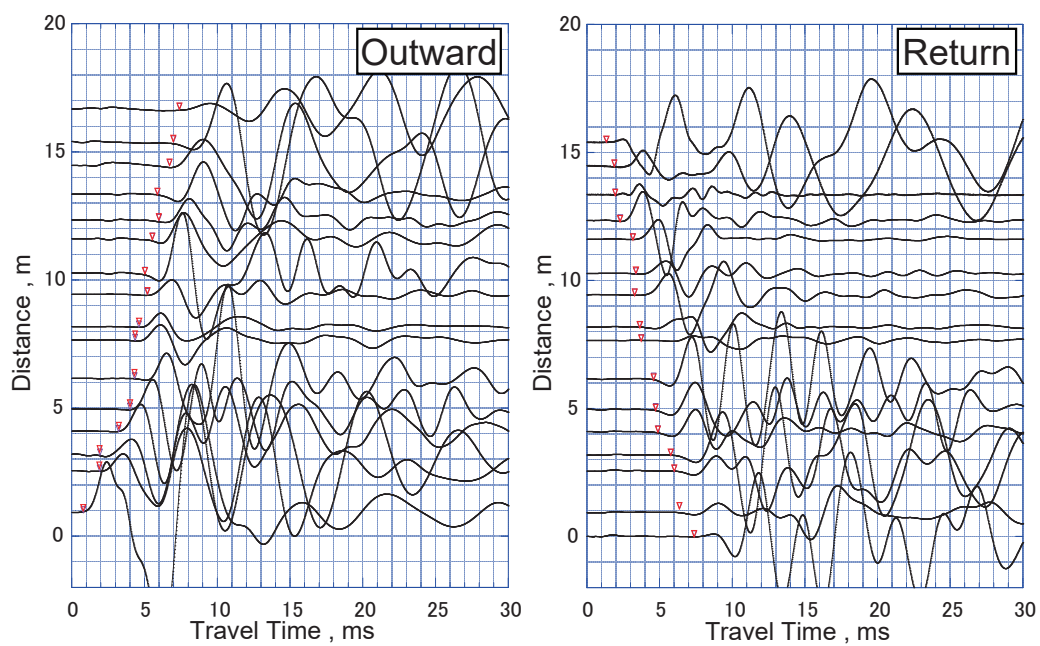

Fig.18 Measurement waveform of rock slope3. 


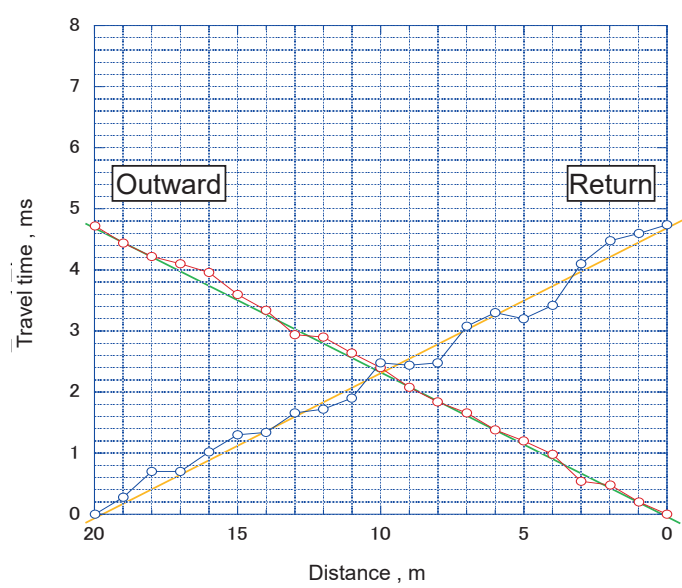

Fig.19 Travel time curve of rock slope1.

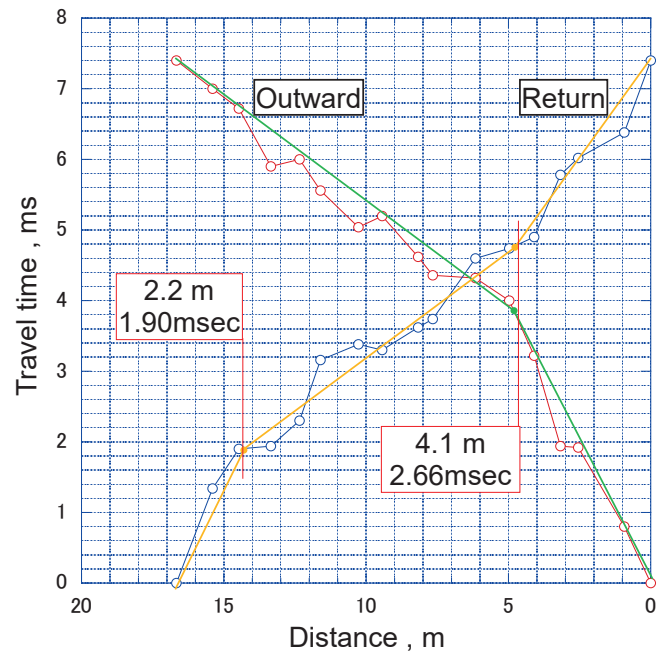

Fig.21 Travel time curve of rock slope3.

ているので，各側線で波形図が 2 枚ある。図中， V印は $\mathrm{P}$ 波初 動の位置を示している。また，残壁ごとに測線長が異なり，測線 長が長くなるほど振幅が小さくなって判別が難しくなるので，最 大值で正規化して表示している。

残壁 1 では往路, 復路ともに単純な波形であり, 減衰も速やか である。また，P波の初動に続く $\mathrm{S}$ 波と考えられる主要動が線状 に並んでいる。これらの特徴は岩盤表面が傷んでいないことを示 唆している。屈折波が現れていないので，明瞭な損傷域がないと 判断できる。

残壁 2 の岩盤表面は残壁 1 と遜色のない良好な状況であった。 しかし，波形は残壁 1 と比較して相当に乱れている。発破による 損傷の影響が残っている可能性が高い。

残壁 3 の表面は発破の影響で凹凸が大きい。波形も残壁 2 以上 に乱れていて周期も長い。このことは残壁 2 の場合よりも岩盤の 損傷が深部にまで及んでいることを示唆している。

（2）走時曲線 Fig. 19〜 Fig. 21 に，P 波が観測点に到達する までの時間と，振源から観測点までの距離の関係を描いた走時曲 線を，残壁 1，残壁 2, 残壁 3 の順に表示した。

残壁 1 の往路は走時がほぼ直線分布となっており，損傷域が認 められない。表面部の值を代表する直接波の速度は $4.22 \mathrm{~km} / \mathrm{s}$ で ある。

残壁 2 では，発振点から往路で $7.5 \mathrm{~m}$, 復路で $5 \mathrm{~m}$ 付近に走時

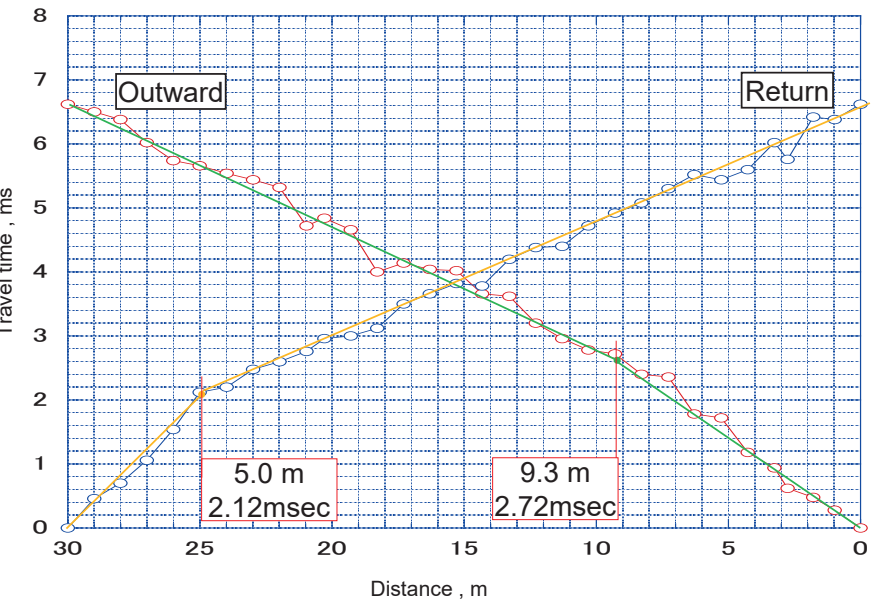

Fig.20 Travel time curve of rock slope2

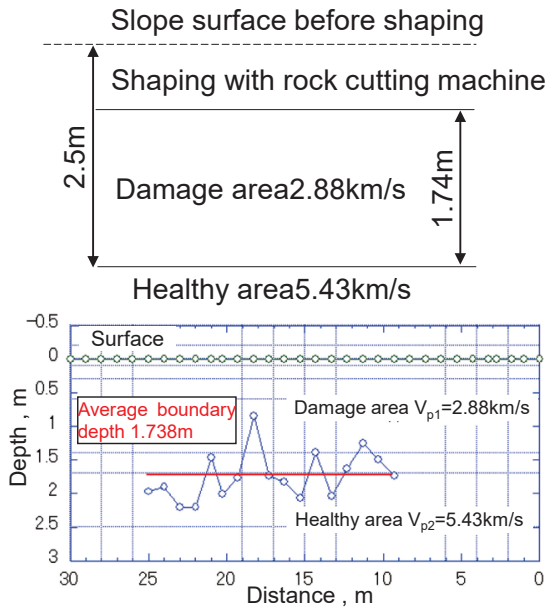

Fig.22 Depth distribution of rock slope2

の折れ曲がりがある。P 波速度は 1 層目が $2.88 \mathrm{~km} / \mathrm{s}, 2$ 層目が $5.43 \mathrm{~km} / \mathrm{s}$ である。1 層目は明瞭な損傷域で, はぎとり法で分析し た結果によれば，その厚さは $0.85 \sim 2.0 \mathrm{~m}$ (平均 $1.74 \mathrm{~m}$ ) である (Fig. 22)。残壁 2 では, 残壁 3 と同じ条件の法面の表層部分を岩 盤切削機で $0.7 \sim 0.8 \mathrm{~m}$ 程度掘削して平滑に仕上げているため, 掘削前の損傷域の厚さは $2.5 \mathrm{~m}$ 程度 (平均) ということになる。2 層目の $\mathrm{P}$ 波速度は残壁 1 よりも速く, 発破の影響はないと考え てよい。この值が健全部の代表值とすると, 残壁 1 では, 応力開 放による緩みが生じている可能性がある。

残壁 3 では, 同様に発振点から往路で $5 \mathrm{~m}$, 復路で $3 \mathrm{~m}$ 付近に折 れ曲がりがある。P 波速度は 1 層目 $1.27 \mathrm{~km} / \mathrm{s}, 2$ 層目 $3.28 \mathrm{~km} / \mathrm{s}$ であ る。1 層目は明瞭な損傷域で, 厚さは $0.3 \sim 1.0 \mathrm{~m}$ (平均 $0.71 \mathrm{~m}$ ) で ある (Fig. 23)。2 層目は，P 波速度が残壁 $1 ・ 2$ の健全部 $(4.22 \mathrm{~km} / \mathrm{s}$, $5.43 \mathrm{~km} / \mathrm{s})$ と比べて $1 \sim 2 \mathrm{~km} / \mathrm{s}$ 遅い。この層は発破の影響を受け た遷移領域であろう。表面には大きな凹凸があり，測定された波 形は最も乱れており，周期も長い。岩盤自体の損傷範囲が広く， 深部にまで影響が及んでいることが推測できる。

$5 \cdot 3 \cdot 2$ 地中レーダ 残壁 $1 \sim 3$ の地中レーダ解析結果 をFig. $25 \sim$ Fig. 27 に示す。図の横軸は測点 0 からの距離を 示す (残壁 2 では測点 $0+1 \mathrm{~m}$ から表示)。縦軸は深度を示 す。残壁 1 および残壁 2 については, 表面の起伏が小さいの で, 表面形状を直線とした。残壁 3 については, 表面形状を 


\section{Slope surface}

\begin{tabular}{cc}
\hline Damage area $1.27 \mathrm{~km} / \mathrm{s}$ & $\frac{\varepsilon}{N}$ \\
& 0 \\
\hline
\end{tabular}

Transition area3.28km/s

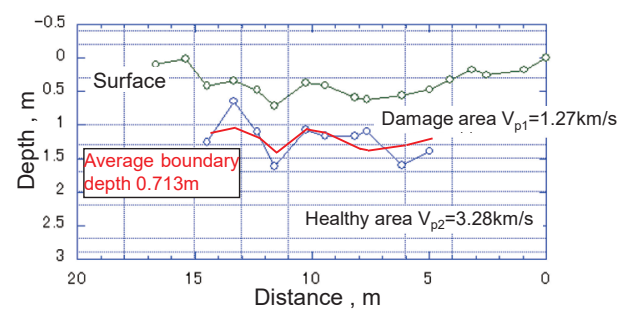

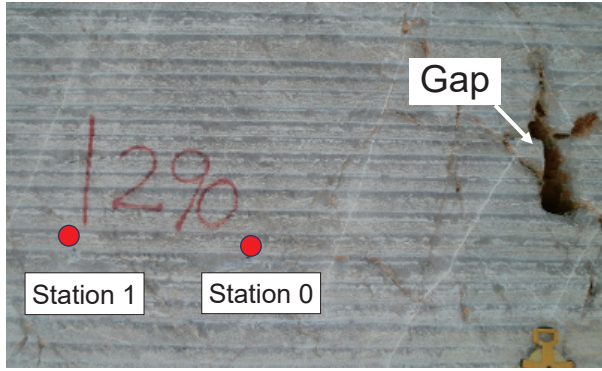

Fig.24 Surface condition on rock slope1

Fig.23 Depth distribution of rock slope3.

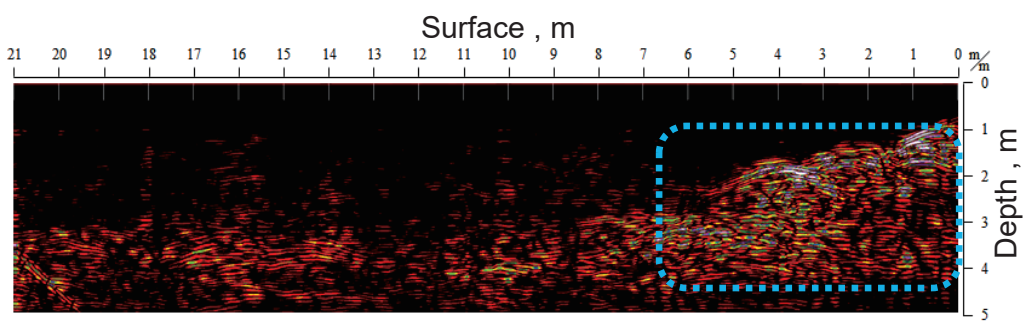

Fig.25 Results of underground radar survey of rock slope1.

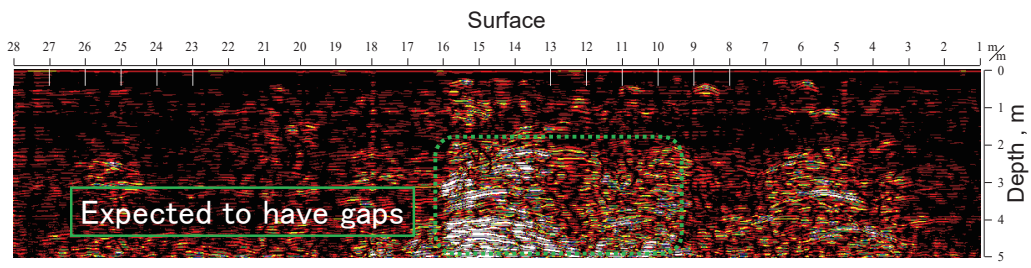

Fig.26 Results of underground radar survey of rock slope2.

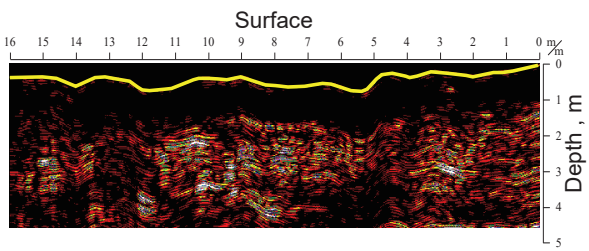

Fig.27 Results of underground radar survey of rock slope3.

黄色い実線で表した。電磁波の振幅の大きさを，小さい方から $[$ 黒 $] \rightarrow[$ 赤 $] \rightarrow[$ 黄 $] \rightarrow[$ 白 ] で色分けした。色の明るい部分は 反射が強く，黒い部分は反射がないことを表している。

（1）残壁 1 測点 1 から近い距離の深部に, 反射の大きくなる 斜めの境界が判別できる。測点 0 付近を撮った Fig. 24 では, 測 点 0 のマイナス側に「はさみ」が確認できるが，この「はさみ」 が測点 0 , 測点 1 の背面側へ回りこんでいるため, 反射の大きな 境界が現れたと推測している (点線で囲った範囲)。測点 0 から の距離が大きくなるにしたがって, 表面近くでは黒い領域が広が り, 深度が大きくなっても明確な反射面がみられない。深度とと もに徐々に反射の大きい領域は現れるが、その境界は判別できな い。これらことは損傷域が存在していないことを示唆している。 （2）残壁 2 Fig. 26 の点線で囲った範囲に示すように、表面近
くから反射する領域が散在している。中間地点の $2 \mathrm{~m}$ 以深で反射 の大きな領域が確認できるため, ガマ(岩石や鉱脈の中に生成し ている空洞）が存在している可能性がある。弾性波探査による健 全部と損傷域の境界 (平均深さ $1.738 \mathrm{~m}$ ) と, 地中レーダによる反 射面との一致は部分的であった。

（3）残壁 3 表面近くでは幅約 $1 \mathrm{~m}$ の黒い領域 ( 反射面があま り見られない) が表面とほぼ並行して存在しており, この領域は 一様な物質とみなせる。破砕によって岩石密度が低下し, 密度 差が減少したことで反射特性が弱まった結果であると考えてい る。弾性波探査による損傷度の強い領域と遷移領域の境界 (深さ $0.713 \mathrm{~m}$ ) と、地中レーダによる反射面 (黄線からの梁さ $0.8 \mathrm{~m}$ ) が 比較的よく一致した。

プレスプリッティング工法 (Fig. 28) は，主発破部より先に外 


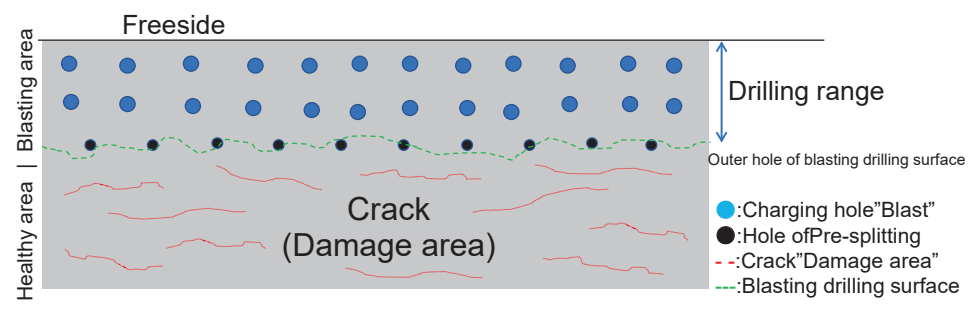

Fig.28 Pre-splitting method.

周孔を発破して外周面にき裂を発生させ，主発破による影響を残 壁から隔離するものである。近接する自由面に対して平行なき裂 を生じさせるが, 発破の影響が残壁深部にまで及ぶ可能性がある。 $5 \cdot 3 \cdot 3$ 赤外線カメラ 法面の表層部分に亀裂や空洞がある と断熱層として機能し, 外部から供給される熱が遮断されて温度 が高くなる。表層付近の含水比によっても温度分布は異なってく る。物体から放射する赤外線を感知する赤外線カメラを使えば, 温度差が可視化できる。

発破面と機械掘削面を遠距離から同時に撮影し，表面温度分 布を比較した (Fig. 29)。近接撮影と遠距離撮影を比較した場合, 後者の方が，温度の局所的な違いが平準化されていて，全体的 な表面温度の違いをより明瞭に判別できた。温度の高い方から， $[$ 白 $] \rightarrow[$ 赤 $] \rightarrow[$ 黄 $] \rightarrow[$ 緑 $] \rightarrow[$ 青 $] \rightarrow[$ 紫 $]$ で色分けした。

（1）残壁 1 Fig. 30 に残壁 1 の赤外線カメラによる画像を示す。 局所的な温度の高まりなどは見られず，全体的に温度変化は小さ い。残壁表面で見られるき裂位置では温度が低くなっているが， き裂内に存在している水の気化熱による温度低下が原因である可 能性が高い。赤外線カメラによる評価では，空洞は見つかってお らず，健全性は高いと考えている。

(2) 残壁 2 Fig. 31 に残壁 2 の赤外線カメラによる画像を示す。 温度の高い領域 ( 図中, 黒点線枠) が散在している。掘削跡が明 瞭な範囲の温度分布は残壁 1 と類似している。近接目視の結果,
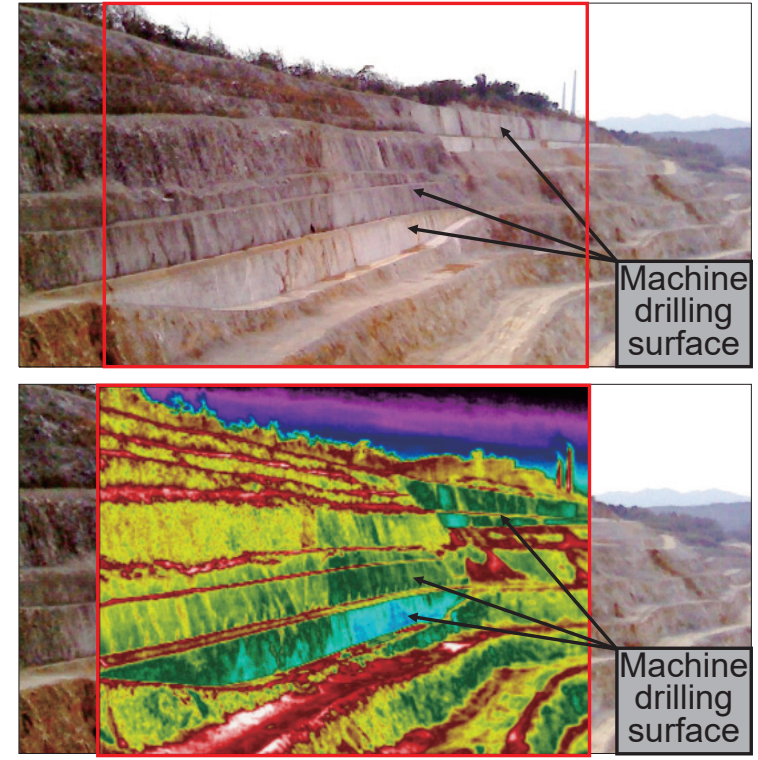

Fig.29 Example of comparison between blasting surface and machine drilling surface by long-distance photography.
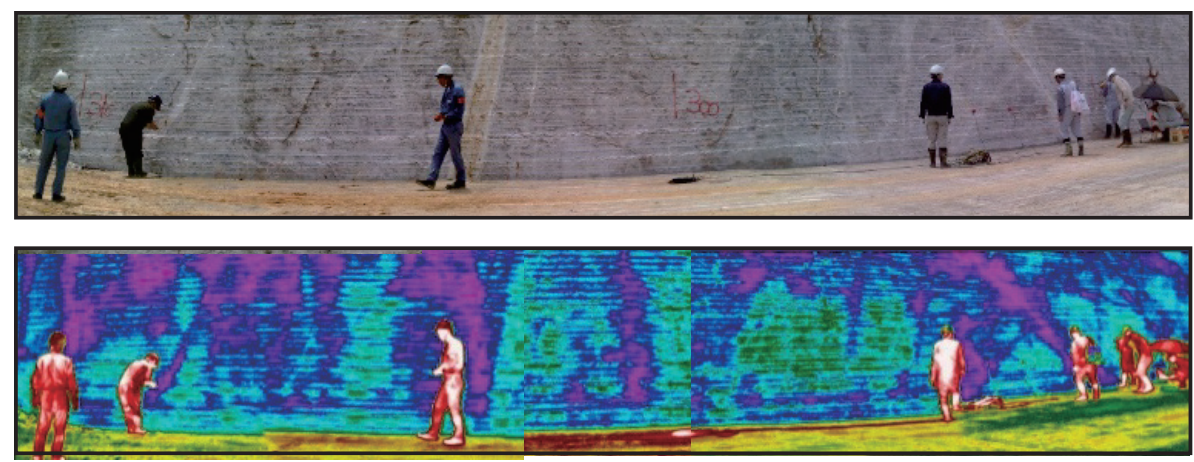

Fig.30 Infrared image of rock slope1 (top: real image, bottom: temperature distribution by infrared).
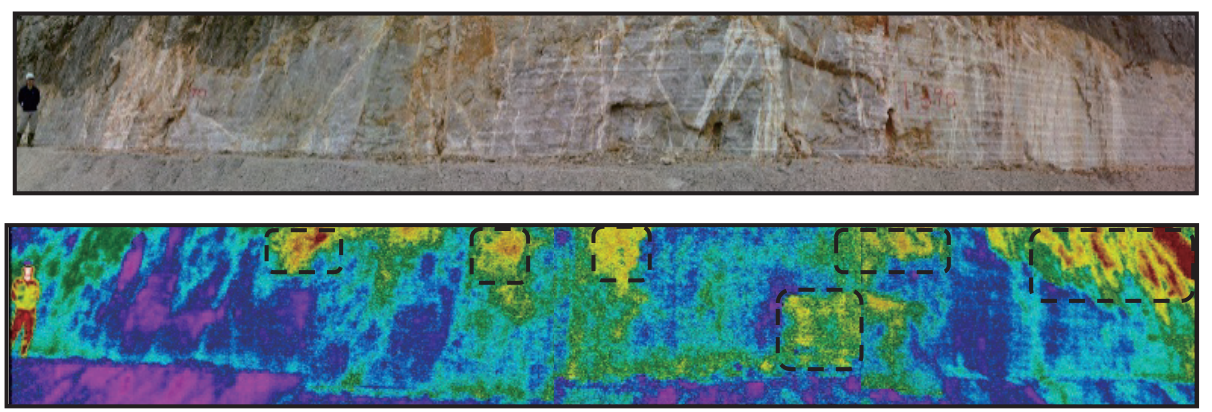

Fig.31 Infrared image of rock slope2 (top: real image, bottom: temperature distribution by infrared). 

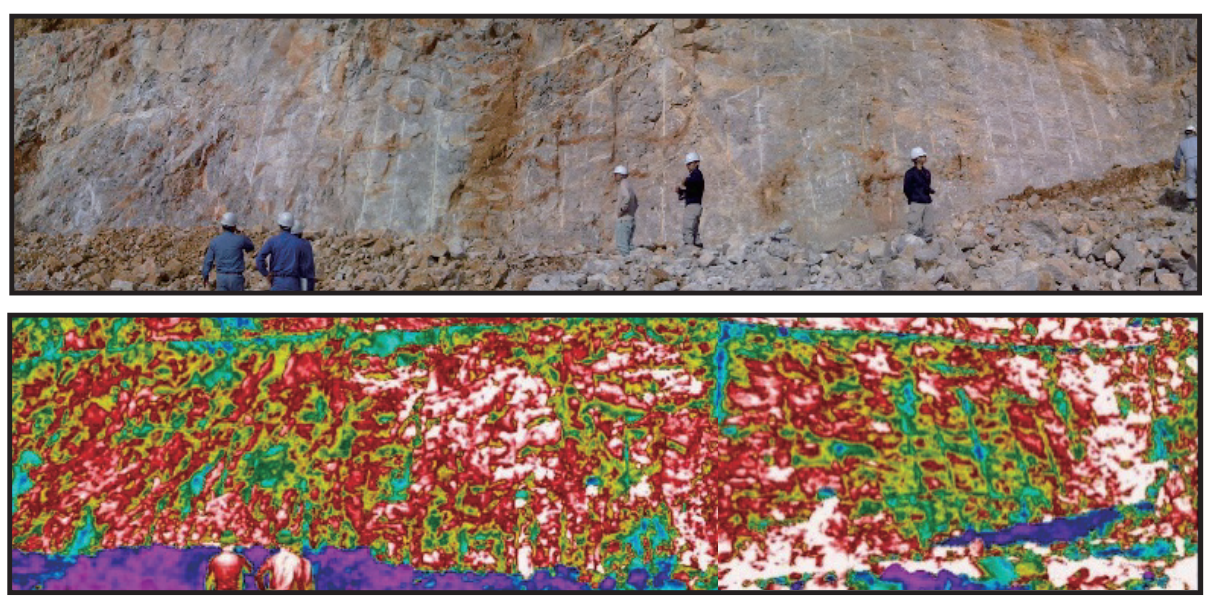

Fig.32 Infrared image of rock slope3 (top: real image, bottom: temperature distribution by infrared).

Table 7 Summary of results.

\begin{tabular}{c|c|l}
\hline Slope & Slope history & \multicolumn{1}{c}{ Slope situation } \\
\hline 1 & Machine drilling & No damage area is seen. \\
\hline 3 & $\begin{array}{c}\text { Machine drilling } \\
7 \text { years after } \\
\text { pre-splitting }\end{array}$ & $\begin{array}{l}\text { Average thickness of the current damage area is about } 1.7 \mathrm{~m} . \\
\text { Thickness of the damage area after pre-splitting is assumed to be about } 2.5 \mathrm{~m} . \\
\text { Elastic wave velocity in the damage area is } 2.88 \mathrm{~km} / \mathrm{s} . \\
\text { Elastic wave velocity of the healthy part is } 5.43 \mathrm{~km} / \mathrm{s} . \\
\text { Speed ratio (damage area/healthy part) is } 53 \% .\end{array}$ \\
\hline 3 & Pre-splitting & $\begin{array}{l}\text { Average thickness of the damage area (high damage level) is about } 0.7 \mathrm{~m} . \\
\text { Elastic wave velocity in the damage area is } 1.27 \mathrm{~km} / \mathrm{s} . \\
\text { Elastic wave velocity in the transition region is } 3.28 \mathrm{~km} / \mathrm{s} . \\
\text { Speed ratio (damage area/transition area) is } 40 \% .\end{array}$ \\
\hline
\end{tabular}

高温領域では，表面の凹凸の向きによって反射熱量に差があるこ と，粘土層などの脆弱層が存在していることが確認できた。全体 的には残壁の健全性は高いと考えている。

（3）残壁 3 Fig. 32 に残壁 3 の赤外線カメラによる画像を示す。 表面の起伏が大きく, それに合わせて温度変化も大きなものと なっており，残壁 1，残壁 2 とは明らかに傾向が異なっている。 現段階で, 表面の起伏や気象条件による影響を完全に排除するこ とは難しいが，今回のような複数の調查を繰り返すことで, 評価 の信頼性を高めることができると考えている。赤外線法は，広い 範囲を効率的に調査できることに加え, その場で熱画像から異常 個所の抽出ができるため, 次段階の調査の必要性を判断したり, 調査計画を作成したりするためのスクリーニングとして有用であ る。

\section{$5 \cdot 3 \cdot 4$ 総合評価}

残壁 1 は, 「測点 $0 」 に$ 近い領域に「はさみ」が存在しているため, 地中レーダの計測では傾斜した反射面が現れた。この領域の走時 曲線は近似した直線からのばらつきが大きくなっている。これも 「はさみ」の影響である可能性が高い。残壁 2 では，弾性波探查 による健全部と損傷域の境界と，地中レーダによる反射面との一 致は部分的であった。残壁 3 では，弾性波探査による損傷度の強 い領域と遷移領域の境界が地中レーダによる反射面と比較的よく 一致した。

残壁 2 と残壁 3 の結果から，プレスプリッティングによる掘削 では表面から $2.5 \mathrm{~m}$ 程度の範囲が損傷を受けていることが分かっ た。残壁 2 では，0.3 1 m の範囲の損傷度合が強く，発破直後 は表面に数十 $\mathrm{cm}$ の凹凸ができるため, 水の浸透や凍結融解の影 響を強く受ける。したがって, 現在の状況は, 経年変化によって 当初よりも損傷領域が広がり, 損傷度も進行している可能性があ る。

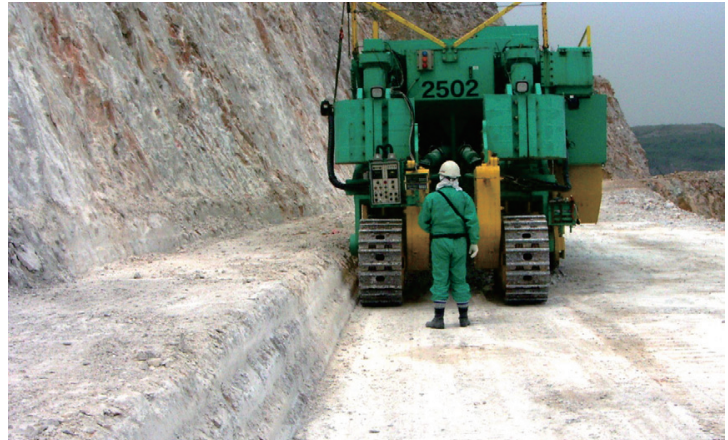

Fig.33 Drilling shoulder with rock cutting machine.

これらの結果をまとめると Table 7 のようである。

$$
\text { 6. ま と め }
$$

\section{$6 \cdot 1$ 岩盤切削による機械掘削工法の評価}

(1) 採掘領域の拡大 岩盤切削機による機械掘削工法を採用寸 ることで，これまで周辺民家に対する環境保全のために発破がで きなかった箇所での採掘が可能になり, 採掘限界ラインを最大で 約 $10 \mathrm{~m}$ 民家側へ移動することができた。同時に, 上・下部切羽 の採掘バランスの改善への展望も開けてきた。

(2) 最終残壁の安全性向上岩盤切削機で造成した掘削法面は 非常に滑らかで安定したものとなっており, 最終残壁の安全性が 格段に向上している。また, 岩盤切削機での掘削では, Fig. 33 に示すように法肩の形状にも大きな乱れがない。発破による掘削 では，前回発破のサブドリリング部の影響などにより法肩からの 落石の危険性が常に付きまとうことを考えると, 岩盤切削機は掘 削法面の安全面での優位性が高い。 


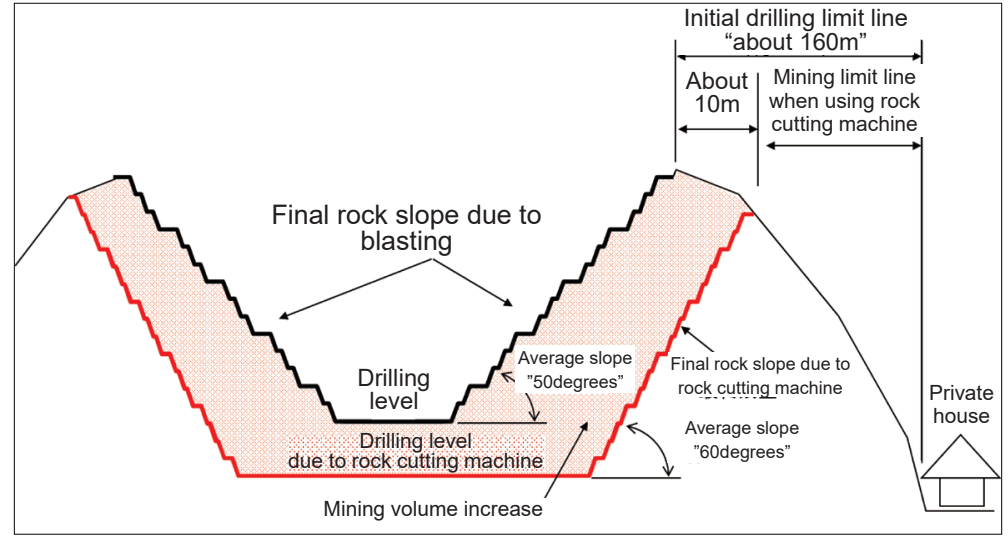

Fig.34 Final excavation concept.

（3）可採鉱量の増加 7) Fig. 34 に終掘時の概念図を示す。岩盤 切削機を導入することで，採掘限界ラインを民家側へ移動するこ とや，最終残壁の平均傾斜をきつくすることが可能になり，可採 鉱量の増加が期待できる。現状での最終残壁の平均傾斜は 50 度 であるが，岩盤切削機を活用することで法面の安定性が向上寸る ため，60 度程度に変更することが可能だと考えている。

当鉱山の採掘切羽はピット状を呈しているため, 終掘レベルは 最下部切羽での作業スペースが確保できるかどうかによって決ま る。Fig. 34 に示すように，採掘限界ラインの移動および最終残 壁の急傾斜化により，最下部切羽のスペースが拡大寸るため，終 掘レベルを下げることも可能になる。それによる可採鉱量の増加 は，丸山鉱区だけでも約 30 百万 $\mathrm{t}$ になる。鉱山の新規開発が環 境保全面から困難となっている現状で，斜面崩落の危険性を減じ つつ可採掘量を増やせることは, 資源確保の観点からも効果が大 きい。

（4）運搬道路としての利用岩盤切削機を導入した付帯効果と して, 掘削面が運搬道路として利用できることが挙げられる。 Fig. 8 のように岩盤切削機での掘削面は平坦で強度の低下もない ため，砕石などを敷かなくてもそのまま走行路になる。降雨など による道路の痛みが少ないため, 維持管理費用やダンプトラック の補修費用などの削減効果が期待できる。

$6 \cdot 2$ 残壁健全性から見た施工方法の評価屈折法弾性波探 查，地中レーダ，赤外線カメラによる結果を基に，残壁の健全性 の違いから施工方法を評価した。プレスプリッティングによる残 壁整形では, 表面から最大 $1 \mathrm{~m}$ 程度の深さまでは損傷を受けやす く, 健全層に変わるのは $2.5 \mathrm{~m}$ 程度の深さからであることが分 かった。

一方，岩盤切削機による残壁については，自然の空洞を除き，
き裂や緩みが少なく, 健全性の高いことが分った。さらに掘削後 の斜面が平滑になるため, 雨水の浸透などによる劣化の進行も緩 やかになる。発破と比較して, 小さい破壊エネルギーで平滑な斜 面を造ることができる岩盤切削機の優位性が明らかになった。

$$
\text { 7.おわりに }
$$

調查した残壁は，施工後の経過期間が短いため，経年変化によ る劣化進展の有無や劣化速度などは不明である。数年後 (例えば 5 年後, 10 年後) に同様な調查を行って、残壁の健全性や岩盤切 削機の有効性を更に詳しく調べるつもりである。また, 岩種によ る損傷程度の違いについても調查を行って, 岩盤切削機の特性を より明確にしたいと考えている。

謝辞弾性波や地中レーダを使った掘削法面の調查にあたり， 熊本大学の尾原 祐三 先生, 吉永 徹様, アールエステクノロジィ 株式会社の平田 篤夫 先生には多大なご指導を賜りました。厚く お礼申し上げます。

\section{References}

1) T.Shoudai,H.Ishida and M.Sankouda : "Introduction of rock cutting machine and its effect in Ube Isa mine" 75th Lime Mining Competition, (2016).

2) T.Shoudai,H.Ishida and M.Sankouda : "Introduction of rock cutting machine and its effect in Ube Isa mine" 75th Lime Mining Competition, (2016) .

3) Y.Takegaki,T.Furukawa and S.Kitamura:CIVIL ENGINEERING JOURNAL 42 (2) 2001, p.50-56.

4) K.Maruyama:Construction Machinery and Equipment, 47 (8) 2011, p.66-72

5) A.Fujimori, M.kawahata and K.Maruyama: Japana Society of Civil Engineers 2017Annual Meeting [VI-513]

6) Y.Okamoto, H.Kuwamoto, T.Shoudai and K.Tsujimoto : Proc.MMIJ Annual Meeting (2018), [1307-09-02]

7) T.Shoudai,H.Ishida and M.Sankouda : "Introduction of rock cutting machine and its effect in Ube Isa mine" 75th Lime Mining Competition, (2016). 